Supporting Information for:

Air Quality Impact of Diffuse and Inefficient Combustion Emissions in Africa (DICE-Africa)

Eloise A. Marais ${ }^{\dagger}{ }^{*}$ and Christine Wiedinmyer ${ }^{*}$

${ }^{\dagger}$ John A. Paulson School of Engineering and Applied Sciences, Harvard University, Cambridge, MA 02138 (emarais@seas.harvard.edu)

${ }^{\ddagger}$ National Center for Atmospheric Research, Boulder, CO 80301 (christin@ucar.edu)

*Corresponding Author

11 pages (including cover page); 4 figures; 6 tables (SI spreadsheet). 


\section{Emissions Estimate}

Here we develop an inventory of Diffuse and Inefficient Combustion Emissions in Africa (DICE-Africa) for 2006 and 2013. Emissions are calculated as the product of the quantity of fuel $i$ burned in each country - the activity factor $(A F)$ - and the mass of each pollutant $j$ emitted per unit of fuel $i$ burned - the emission factor $(E F)$ :

$$
E_{i, j}=C E \quad A F_{i} \quad E F_{i, j}
$$

where $E_{i, j}$ is the country-level emission of pollutant $j$ for fuel $i$ mapped to a $0.1^{\circ} \times 0.1^{\circ}$ grid and $C E$ is the conversion efficiency of fuel carbon to $\mathrm{CO}_{2}$ used to account for reduced burning efficiency of solid fuels (crop residue, fuelwood, and charcoal) that smolder $(C E=0.8)$ or flame $(C E=0.99) .{ }^{1} C E=1$ for liquid fuels (kerosene, gasoline, and diesel) and natural gas. Data used to obtain $A F_{i}$ are from the UN data portal ${ }^{2}$, unless otherwise stated here or in the SI spreadsheet (Tables S2-S5). In the case that data are missing, we use country-level reports where available; otherwise data from neighboring countries with similar socioeconomic status are applied. Approaches to estimate $A F_{i}$ and spatially allocate $E_{i, j}$ are described below for each fuel type. Values of $E F_{i, j}$ are in Table S6.

Values of $E_{i, j}$ are gridded to LandScan 2006 (Figure S1) ${ }^{3}$ and $2013^{4}$ population data gridded from the native grid $(1 \mathrm{~km} \times 1 \mathrm{~km})$ to $0.1^{\circ} \times 0.1^{\circ}$ for crop residue, fuelwood, charcoal, and kerosene use, charcoal production, and gasoline (petrol) and diesel for cars, motorcycles, and backup generators. Gas flare $E_{i, j}$ are gridded to satellite observations of gas flare hotspots, ${ }^{5}$ and ad hoc oil refining $E_{i, j}$ are uniformly distributed across land area in the Niger Delta where ad hoc oil refining has been documented. ${ }^{6}$ 


\subsection{Energy from solid biofuels, kerosene, and backup generators}

Fuelwood used to satisfy energy needs in households and commercial settings, provided as volume dry mass, ${ }^{2}$ is converted to fuelwood mass (Tables S2 and S3) using an average fuelwood density of tropical trees in Africa, $580 \mathrm{~kg} \mathrm{~m}^{-3}{ }^{7}$ We assume a mix of smoldering and flaming conditions $(C E=0.9){ }^{8}$ and spatially allocate fuelwood use to both urban and rural populations, as wood is an energy source for both. ${ }^{9}$ We use a population density threshold of 1000 people $\mathrm{km}^{-2}$ at the LandScan native resolution $(1 \mathrm{~km} \times 1 \mathrm{~km})$ to distinguish rural and urban populations. Figure S1 shows the distribution of urban populations in 2006 re-gridded to $0.1^{\circ} \times 0.1^{\circ}$

Household burning of crop residue is determined by assigning each country to an agroclimatic zone. ${ }^{10}$ Crop residue used for energy generation is then estimated with crop production data, ${ }^{11}$ and reported estimates of crop residue generated for each crop type, and the fraction of crop residue allocated to energy generation. ${ }^{12}$ Dry mass of crop residue burned in each country is listed in Tables S2 (2006) and S3 (2013). Crop residue burning is predominantly flaming (CE = 0.95). ${ }^{13}$ Emissions are distributed across rural populations only. ${ }^{14}$

Animal dung is another energy source used in Africa, but is not considered here. Reported usage data are limited and the contribution of dung to total dry matter burned is likely small $(<3 \%) .^{12}$

Household charcoal consumption for each country is listed in Table S2 for 2006 and Table S3 for 2013. Combined flaming and smoldering burning is assumed $(C E=0.9)$. Charcoal typically replaces fuelwood in urban households, and so charcoal use is only allocated to urban populations. ${ }^{15}$

Indoor use of kerosene for lighting and cooking follows the approach of Lam et al. ${ }^{16}$, that is, $89 \%$ of indoor residential kerosene consumed (in tonnes; Tables S2 and S3) escapes to the outdoors. 
Backup generator use is reported for individual countries as the percent contribution to installed capacity (Table S4) and emission factors are reported per unit electricity generated (Table S6). We estimate electricity generated with backup generators for each country using reported installed electricity capacity for 2006 and 2013 (Table S4); ${ }^{17}$ and an energy conversion efficiency of $25 \% .^{18}$

\subsection{Gasoline and Diesel for Cars and Motorcycles}

The amount of fuel (diesel and gasoline) burned by cars and motorcycles is determined using the approach of Assamoi and Liousse. ${ }^{19}$ Briefly, total diesel and gasoline used in the transport sector (in tonnes) ${ }^{2}$ is apportioned between cars and motorcycles. We first estimate the amount of fuel used by motorcycles with car ownership data, motorcycle-to-car ownership ratios (Table S5 and references therein), and assuming $5 \mathrm{~L} \mathrm{day}^{-1}$ fuel consumption by motorcycles. ${ }^{19}$ Fuel used by cars is then the difference between total fuel reported by the UN and our estimate of fuel used by motorcycles. The resultant fuel estimates for cars and motorcycles is in Table S2 for 2006 and Table S3 for 2013.

\subsection{Charcoal Production}

The mass of fuelwood used to generate charcoal is determined from UN charcoal production data for each country by applying a wood-to-charcoal conversion factor of $20 \% .^{12}$ Wood smolders during charcoal production, so $C E=0.8{ }^{1}$

\subsection{Gas Flares and Niger Delta Ad Hoc Oil Refining}

Gas flare volumes for individual countries (in billions $\mathrm{m}^{3}, \mathrm{BCM}$ ), estimated from spacebased observations of nighttime lights, are reported for year 2008 for dominant flaring countries ${ }^{5}$ and for 2006 for minor contributors. ${ }^{20}$ These gas flare volumes are used here, with Defense Meteorological Satellite Program (DMSP) nightlights, ${ }^{21}$ to determine volume of gas flared in 
2006 and 2013. NOAA shape files ${ }^{22}$ are used to distinguish gas flares from other nighttime lights. Reported gas flare volumes are scaled to 2006 and 2013 using annual trends in gas flares following intercalibration of DMSP sensors using the approach of Elvidge et al. ${ }^{5}$ Flaring volumes for each country, listed in Table S2 for 2006 and Table S3 for 2013, are spatially allocated to individual gas flare hotspots at $1 \mathrm{~km} \times 1 \mathrm{~km}$ resolution and then re-gridded to $0.1^{\circ} \times 0.1^{\circ}$

Ad hoc oil refining is limited to the Niger Delta and includes in this inventory pollution from burning crude oil to sustain wood fires during distillation, and volatilization of gases from the crude oil and refined product during transport, storage, and distillation. As much as 37,500 barrels per day (bpd) crude oil is refined in the Niger Delta. ${ }^{6}$ We assume $2.5 \%$ of this oil is used to sustain wood fires during distillation $(940 \mathrm{bpd})$. We use industrial distillation emission factors for fugitive emissions, and oil spill fire emission factors for pollution from burning crude oil (Table S6). Oil refining emissions are allocated to land area in the Niger Delta using the NOAA Niger Delta shape file. ${ }^{22}$ 


\section{FIGURES:}
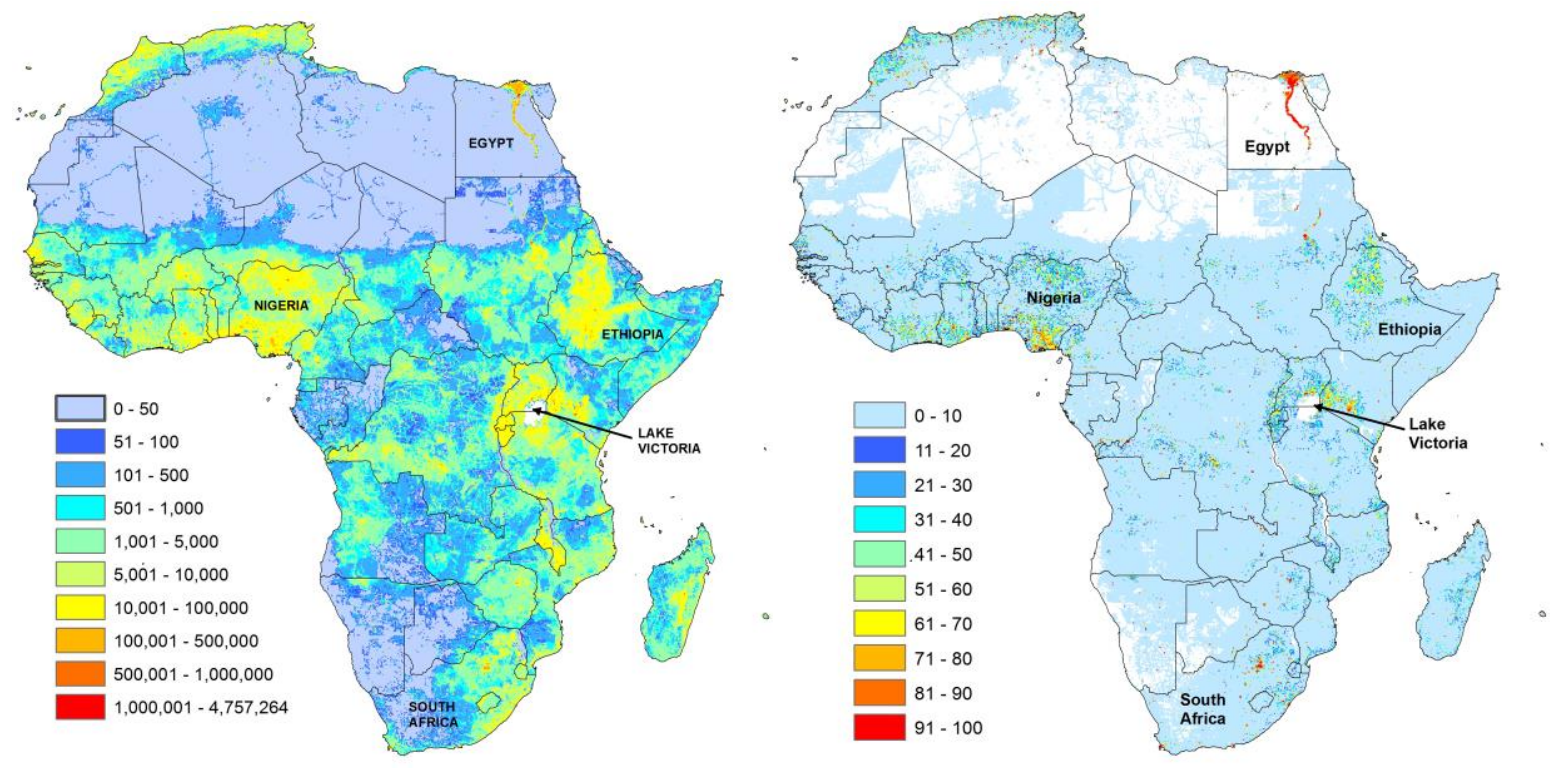

Figure S1. Population density (left) and percent urban population (right) for 2006 at $0.1^{\circ} \times 0.1^{\circ}$. Population distribution is from the Landscan dataset ${ }^{3}$ and urban population is identified with a population threshold of 1000 people $\mathrm{km}^{-2}$ at the native Landscan resolution $(1 \mathrm{~km} \times 1 \mathrm{~km})$. 


\section{Sector emissions of NMVOCs, $\mathrm{OC}, \mathrm{SO}_{2}$, and $\mathrm{NH}_{3}$ in 2006 \\ NMVOCs (14 Tg) \\ OC (1.8 Tg C)}

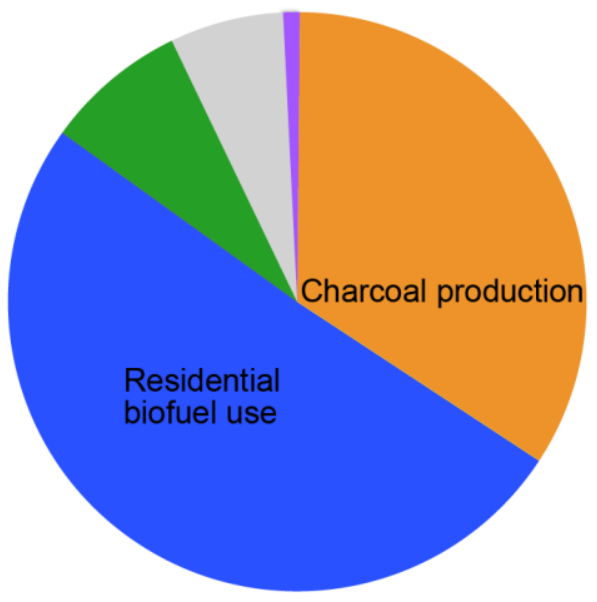

$\mathrm{SO}_{2}(0.22 \mathrm{Tg})$

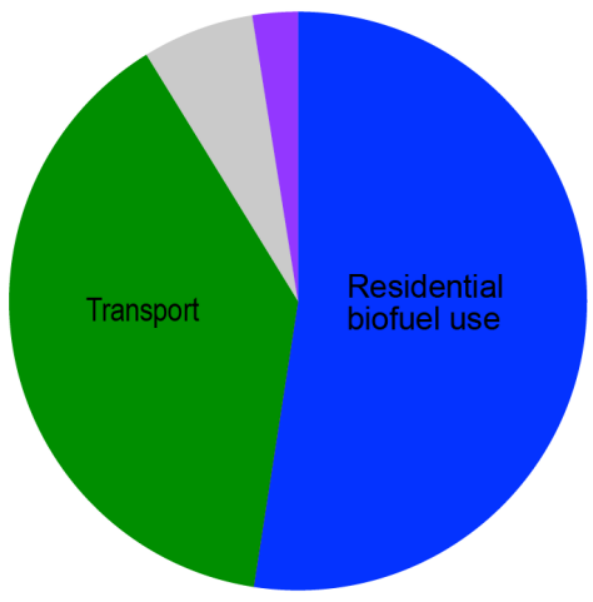

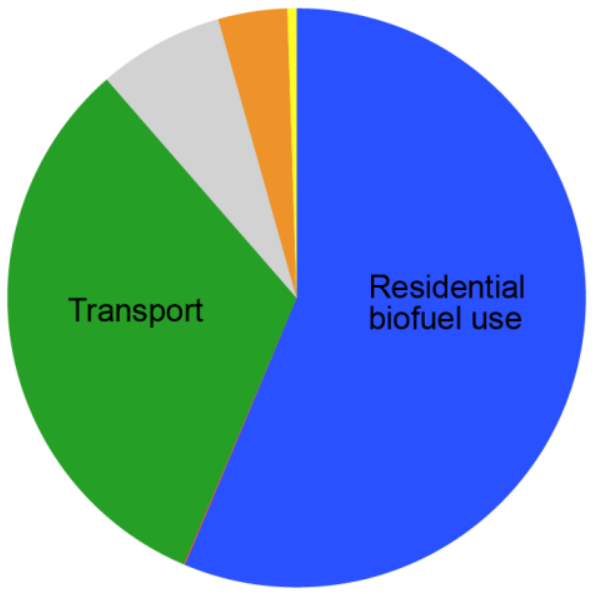

$\mathrm{NH}_{3}(0.18 \mathrm{Tg})$

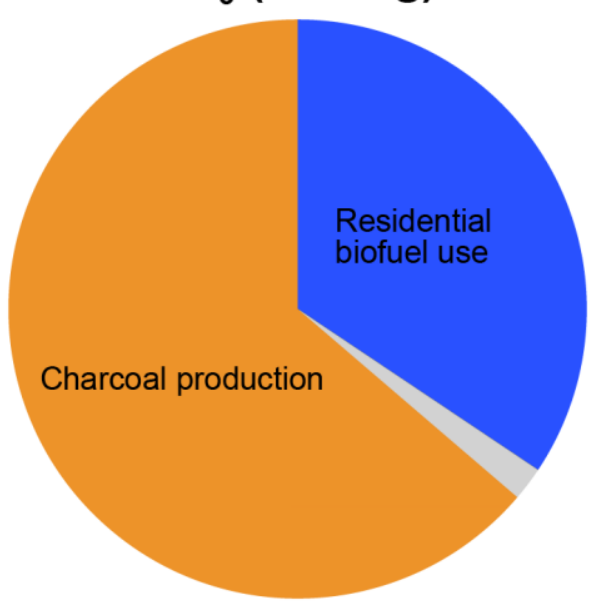

Figure $\mathrm{S} 2$. Sources of NMVOCs, $\mathrm{OC}, \mathrm{SO}_{2}$, and $\mathrm{NH}_{3}$ by sector in 2006. Labels are shown for sectors that make at least $10 \%$ contribution to total emissions. Residential biofuel use includes crop residue, fuelwood, and charcoal, transport includes gasoline (petrol) and diesel consumption by cars and motorcycles, commercial biofuel use is fuelwood only. 

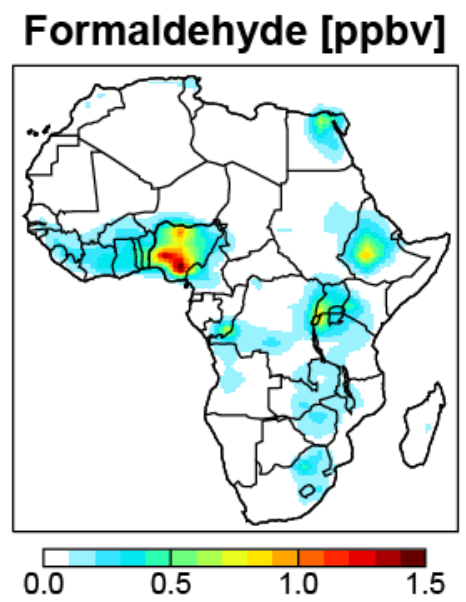

Benzene [ppbv]

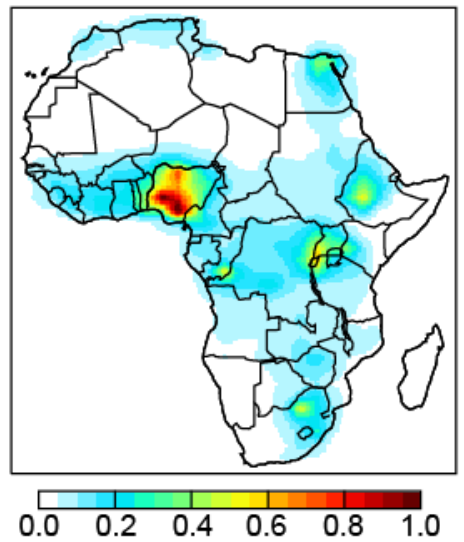

Figure S3. Air quality impact of diffuse and inefficient sources of combustion. Maps show annual mean surface formaldehyde, and benzene for 2006 obtained as the difference in a GEOSChem simulation with and without pollution sources calculated in this work. Formaldehyde includes secondary and primary sources. ${ }^{23}$ Of the primary sources, residential fuelwood use $(55 \%)$ and charcoal production $(26 \%)$ dominate. Benzene is mainly from commercial and residential fuelwood burning (73\%), and transport (17\%). 


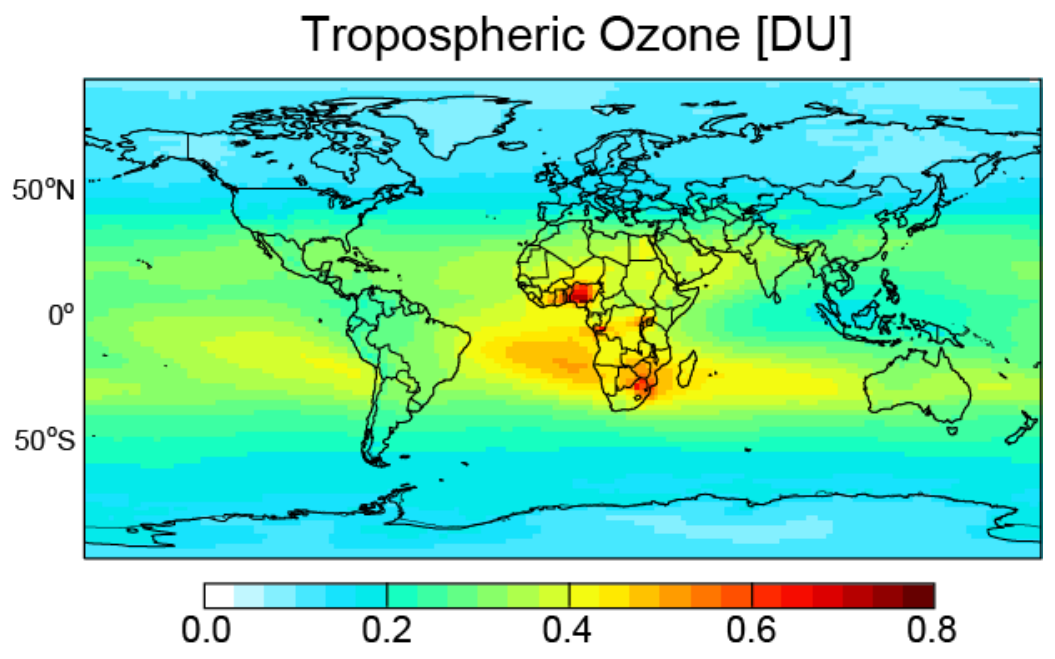

Figure S4. Contribution of diffuse and inefficient pollution sources to global tropospheric ozone. The map shows annual mean tropospheric ozone for 2006 obtained as the difference in a GEOSChem simulation with and without pollution sources calculated in this work. DU $=2.69 \times 10^{16}$ molecules $\mathrm{cm}^{-2}$. 


\section{REFERENCES}

1. Akagi, S. K.; Yokelson, R. J.; Wiedinmyer, C.; Alvarado, M. J.; Reid, J. S.; Karl, T.; Crounse, J. D.; Wennberg, P. O., Emission factors for open and domestic biomass burning for use in atmospheric models. Atmos. Chem. Phys. 2011, 11, 4039-4072, doi:10.5194/acp-11-40392011.

2. UN, United Nations (UN) Data Portal, Energy Statistics Database, United Nations Statistics Division (UNSD). http://data.un.org/Explorer.aspx?d=EDATA 2015 [Accessed: August 19-30, 2015].

3. Bright, E. A.; Coleman, P. R.; King, A. L., LandScan 2006. In 2006 ed.; Oak Ridge National Laboratory: Oak Ridge, TN, 2007.

4. $\quad$ Bright, E. A.; Rose, A. N.; Urban, M. L., LandScan 2013. In 2013 ed.; Oak Ridge National Laboratory: Oak Ridge, TN, 2014.

5. Elvidge, C. D.; Ziskin, D.; Baugh, K. E.; Tuttle, B. T.; Ghosh, T.; Pack, D. W.; Erwin, E. H.; Zhizhin, M., A Fifteen Year Record of Global Natural Gas Flaring Derived from Satellite Data. Energies 2009, 2, 595-622, doi:10.3390/en20300595.

6. SDN, Communities Not Criminals: Illegal Oil Refining in the Niger Delta; Stakeholder Democracy Network (SDN): London, UK, October 16, 2013.

7. FAO, Food and Agriculture Organization (FAO), Estimating Biomass and Biomass Change of Tropical Forests: a Primer, FAO Forestry Paper - 134, Appendix 1. http://www.fao.org/docrep/w4095e/w4095e00.htm, 1997 [Accessed: August 6, 2015]. 8. Liousse, C.; Penner, J. E.; Chuang, C.; Walton, J. J.; Eddleman, H.; Cachier, H., A global three-dimensional model study of carbonaceous aerosols. J. Geosphys. Res. 1996, 101, 1941119432, doi:10.1029/95jd03426.

9. Ardayfio-Schandorf, E., The fuelwood/energy crisis in Sub-Saharan Africa. In Sustaining the Future: Economic, Social, and Environmental Change in Sub-Saharan Africa, Benneh, G.; Morgan, W. B.; Uitto, J. I., Eds. Princeton Academic Press: New York, NY, 1996.

10. HarvestChoice, Agro-ecological Zones of Sub-Saharan Africa. http://harvestchoice.org/node/8853, 2010 [Accessed: August 6, 2015].

11. FAO, Food and Agriculture Organization (FAO), FAOSTAT. http://faostat.fao.org/site/567/default.aspx - ancor, 2014 [Accessed: August 4, 2015]. 12. Yevich, R.; Logan, J. A., An assessment of biofuel use and burning of agricultural waste in the developing world. Global Biogeochem. Cy. 2003, 17, doi:10.1029/2002gb001952.

13. Stockwell, C. E., et al., Trace gas emissions from combustion of peat, crop residue, domestic biofuels, grasses, and other fuels: configuration and Fourier Transform InfraRed (FTIR) component of the fourth Fire Lab at Missoula Experiment (FLAME-4). Atmos. Chem. Phys. 2014, 14, 9727-9754, doi:10.5194/acp-14-9727-2014.

14. de Leeuw, P. N., Crop residue in tropical Africa: trends in supply, demand and use. In Crop residue in sustainable mixed crop/livestock farming systems, Renard, C., Ed. CAB International: Wallingford, UK, 1997.

15. Girard, P., Charcoal production and use in Africa: what future?; International Cooperation Centre of Agricultural Research for Development (CIRAD-Forêt): Montpellier, France, 2002.

16. Lam, N. L., et al., Household light makes global heat: High black carbon emissions from kerosene wick lamps. Environ. Sci. Technol. 2012, 46, 13531-13538, doi:10.1021/es302697h. 
17. EIA, US Energy Information Administration (EIA), International Energy Statistics: Total Electricity Installed Capacity. http://www.eia.gov/cfapps/ipdbproject/IEDIndex3.cfm, 2015 [Accessed: March 2, 2016].

18. UNDP, Standardized Baseline Assessment for Rural Off-Grid Electrification in SubSaharan Africa; United Nations Development Programme (UNDP): Addis Ababa, Ethiopia, November, 2013.

19. Assamoi, E. M.; Liousse, C., A new inventory for two-wheel vehicle emissions in West Africa for 2002. Atmos. Environ. 2010, 44, 3985-3996, doi:10.1016/j.atmosenv.2010.06.048. 20. Elvidge, C. D.; Baugh, K. E.; Tuttle, B. T.; Howard, A. T.; Pack, D. W.; C., M.; Erwin, E. H., A Twelve Year Record of National and Global Gas Flaring Volumes Estimated Using Satellite Data: Final Report to the World Bank; NOAA: Boulder, CO, May 30, 2007.

21. http://ngdc.noaa.gov/eog/dmsp/downloadV4composites.html, [Accessed: July 10, 2015].

22. http://ngdc.noaa.gov/eog/interest/gas flares countries shapefiles.html, [Accessed: July 14, 2015].

23. Fortems-Cheiney, A., et al., The formaldehyde budget as seen by a global-scale multiconstraint and multi-species inversion system. Atmos. Chem. Phys. 2012, 12, 6699-6721, doi:10.5194/acp-12-6699-2012. 